\title{
Farklı Çevresel Şartlarda İki Eksenli Yüklemelere Maruz Tabakalı Kompozit Malzemelerin Hasarı
}

\author{
Fatih DARICIK*1, Sakine KIRATLI ${ }^{2}$ \\ ${ }^{1}$ Alanya Alaaddin Keykubat Üniversitesi, Makine Mühendisliği Bölümü, Antalya \\ ${ }^{2}$ Çankırı Karatekin Üniversitesi, Makine Mühendisliği Bölümü, Çankırı
}

Geliş tarihi: 03.03.2021

Kabul tarihi: 31.03 .2021

Öz

Polimer matrisli tabakalı kompozit malzemelerin bileşenlerinin dayanım yönünden çok farklı olması bu malzeme grubunun hasar analizlerini zorlaştırmaktadır. Tabakalı kompozitlerin hasar analizleri için önerilen birçok hasar ölçütü bulunmaktadır. Bu çalışmada iki yönde düzlemsel yayılı yüke ve bir yönde yayılı yük ile kayma yüküne maruz S-cam lifi/epoksi ve karbon lifi/epoksi tabakalı kompozit malzemelerin Tsai-Wu ve Puck ölçütüne göre hasarı araştırılmıştır. Birçok yükleme halinde Puck ölçütü daha güvenli hasar zarfları göstermektedir. Ancak hangi hasar ölçütünün daha güvenli olduğu tabakalı kompozit malzemelerin türüne, çevresel şartlara, takviye lif açılarına ve yüklemenin işaretine göre farklılıklar göstermektedir. Her iki malzeme türünün hem açılı hem de çapraz katlı tasarımları için tüm iki eksenli yüklemelerde malzeme dayanımını en çok düşüren etken ortam nemidir. S-cam lifi/epoksi tabakalı kompozitlerde Puck ölçütü ile oluşturulan hasar zarfları ortam sıcaklığından daha fazla etkilenirken, karbon lifi/epoksi tabakalı kompozit malzemelerde Tsai-Wu ölçütü ortam sıcaklığı değişimine karşı daha duyarlı davranış göstermiştir.

Anahtar Kelimeler: Tabakalı kompozitler, İki eksenli yükleme, Çevresel şartlar, Hasar zarfları

\section{Damage of Laminated Composite Materials Exposed to Biaxial Loads in Different Environmental Conditions}

\begin{abstract}
The fact that the components of the polymer matrix laminated composite materials are very different in terms of strength makes the damage analysis of the materials difficult. There are many damage criteria recommended for damage analysis of laminated composites. In the present study, the damage of S-glass fiber/epoxy and carbon fiber/epoxy laminated composite materials subjected to planar distributed loads in two directions and also a planar distributed load with shear load was investigated according to Tsai-Wu criterion and Puck criterion. Puck criterion indicates more conservative damage envelopes in many loading cases. However, which of the criterions is more conservative varies according to the type of laminated composite materials, environmental conditions, orientation of fiber reinforcements and the sign of loading. For both the angle-ply and cross-ply stacking of both the laminated composite materials, it is
\end{abstract}

"Sorumlu yazar (Corresponding author): Fatih DARICIK, fatih.daricik@alanya.edu.tr 
the ambient humidity that decreases the material strength the most in all biaxial loadings. For the S-glass fiber/epoxy laminated composites, failure envelopes created by the Puck criterion were affected more by ambient temperature, while for the carbon fiber/epoxy layered composites Tsai-Wu criterion showed more sensitive behavior due to ambient temperature changes.

Keywords: Laminated composites, Biaxial loading, Environmental conditions, Failure envelopes

\section{GíRiș}

Kompozit malzemeler, birçok özelliği yanında hafiflik, yüksek dayanım ve rijitlik gibi temel özellikleri nedeniyle geleneksel malzemelere tercih edilmektedir. Kompozit malzemelerden cam elyaf takviyeli (CTP) ve karbon elyaf takviyeli (KTP) kompozit silindirik yapıların endüstriyel kullanımı oldukça yaygındır. Özellikle CTP borular petrol, doğalgaz, jeotermal akışkan, kullanılabilir su, atık su iletim hatlarında ve daha birçok mühendislik uygulamasında kullanılmaktadır [1-3]. CTP borular ve tüpler kullanım alanları içerisinde bileşke veya tekil halde çekme, basma, iç basınç ve dış basınç yüklemelerine maruz kalmaktadır. Örneğin gömülü borular hem iç basınca hem diş basinca hem de eğme yüklerine maruzdur. Diğer yandan boru içindeki akışkan sıcaklığı ve borunun gömülü bulunduğu ortam sicaklığı da termal gerilmeler oluşturmaktadır. Açık denizlerde gömülü bulunan boru hatları, iletimini yaptıkları akışkanın iç basıncına maruz iken deniz suyunun hidrostatik basıncı altındadır. Bu nedenle silindirik kompozit malzemelerin değişken ortam sıcaklıklarında tekil ve bileşke yüklere karşı dayanım göstermeleri mühendislik uygulamalarının sürdürülebilirliği adına önem arz etmektedir.

Araştırmacılar, polimer matrisli çeşitli elyaflarla (cam, karbon ve aramid) takviye edilmiş kompozit silindirlerin iki eksenli yüklemesine yönelik olarak analitik, nümerik ve deneysel çalışma yapmışlardır. Quaresimin, Carraro ve Maragoni (2015) cam lifi/epoksi tüplerin çekme-burulma yükleri altında çift eksenli yorulma davranışını incelemişlerdir [4]. Yaptıkları analizlerde ilk çatlak başlangıcı ve çatlak ilerlemesinde her iki parametrenin de (çift eksenlilik ve yük oranı) güçlü etkisi olduğunu görmüşlerdir. Perillo vd. (2014) cam lifi/vinilester ve karbon lifi/epoksi kompozit tüplerin hasar zarflarını değerlendirmek için dört kombinasyonlu yükleme (saf eksenel, saf kayma, kayma+eksenel, eksenel+kayma) yapmışlardır [5]. Deneysel olarak bulunan hasar zarflarını, çeşitli hasar ölçütleriyle (maksimum gerilme, Tsai-Wu, Tsai-Hill, Hashin, Puck) yapılan tahminlerle karşılaştırmışlar ve Puck ölçütünün hasar zarfını doğru bir şekilde tahmin etme kabiliyeti olduğunu bulmuşlardır. Quaresimin ve Carraro (2013) tek yönlü cam lifi/epoksi kompozit tüplerin çekme-burulma yüklemesi altında çok eksenli yorulma özelliklerini araştırmışlardır [6]. Çekme ve burulma rijitliğinin ani bir düşüş sergilediğini tespit etmişlerdir. Reddy ve Krishna (2012) saf ve bileşik yükleme altındaki karbon lifi/epoksi, E-cam lifi/epoksi, aramid lifi/epoksi kompozit tüpleri ANSYS paket programını kullanarak modellemişlerdir [7]. Tek eksenli, çift eksenli, üç eksenli ve çok eksenli yüklemeler altında her üç malzeme için gerilme ve rijitliği inceleyerek optimum açıları tespit etmiş ve en uygun malzemeyi seçmişlerdir. Bakaiyan, Hosseini ve Ameri (2009) iç basınç ve bir sıcaklık gradyanı altında $[+55 /-55 /+55 /-55]$ ve $[+55 /-$ $55 /+30 /-30$ ] dizilime sahip silindirik boruların 1sıl gerilmeleri ve deformasyonları için tam bir elastik çözüm sunmuşlardır [8]. Çevresel-eksenel gerilmenin, fiber oryantasyonu çevresel yöne eğilim gösterdikçe arttığını, fiber oryantasyonu eksenel yöne yöneldiğinde ise azaldığı sonucuna ulaşmışlardır. Çallioğlu, Ergun ve Demirdag (2008) iç basınç ve termal yüklemeye maruz (0/90), (30/-30), (45/-45) ve (60/-60) oryantasyonlarında cam lifi/epoksi kompozit silindirlerde gerilme fonksiyonu yaklaşımı kullanarak analitik bir çözüm sunmuşlardır [9]. Yaptıkları analizlerde radyal, teğetsel ve eksenel gerilme bileşenlerinin hem çapraz katlı hem de açılı katlı silindirler için değişmediğini bulmuşlardır. Li ve Shen (2008) yanal ve eksenel basınç etkisi altındaki \pm 55 filaman sargılı E-cam lifi/epoksi silindirik elemanların termal ortam koşullarında burkulma sonrası davranışını teorik 
ve nümerik olarak araştırmışlardır [10]. Burkulma davranışının sıcaklık ve fiber hacim oranından etkilendiği, burkulma sonrası davranışın ise yüke bağlı olarak değiştiği sonucuna ulaşmışlardır. Liu, Soden ve Kaddour (2005) \pm 55 sarım açısına sahip E-cam lifi/epoksi kompozit tüpleri iki eksenli basma (dış basınç ve eksenel basma) altında nümerik ve deneysel olarak araştırmışlardır [11]. ABAQUS ile yapilan sonlu eleman analizi ve deneysel şekil değiştirme dağılımları arasında iyi bir korelasyon olduğunu bulmuşlardır. Xia, Kemmochi ve Takayanagi (2001) iç basınç ve sıcaklık değişimine maruz kalan E-cam lifi/epoksi sandviç borudaki termal gerilmeler ve birim şekil değiştirmeleri analitik ve nümerik olarak incelemişlerdir [12]. Yaptıkları analizde iç basınç altında sandviç borunun eksenel şekil değiştirmesinin sarım açısına göre değişmediğini gözlemlemişlerdir. Martens ve Ellyin (2000) $\left[ \pm 66_{4}, 0, \pm 66_{3}, 0, \pm 66_{3}, 0, \pm 66_{5}, 0\right]$ oryantasyonlu cam lifi/epoksi bir borunun çift eksenli monotonik davranışını deneysel olarak araştırmışlardır [13]. Ayrıca eksenel ve çevresel yönlerdeki rijitlik ve Poisson oranındaki değişime bakmışlardır. Sızıntı hasarından önce rijitlik ve Poisson oranında önemli bir nonlineer değişiklik olduğu sonucuna ulaşmışlardır. Gargiulo, Marchetti ve Rizzo 1996) $\pm 35, \pm 55, \pm 75$ filaman sarg1l1 karbon lifi/epoksi ince tüplerin çift eksenli yükleme koşullarında mukavemetini deneysel ve nümerik olarak incelemişlerdir [14]. Maksimum gerilme, TsaiHill, Tsai-Wu ve Hoffman hasar ölçütlerini kullanmışlar ve Tsai-Wu hasar ölçütünün deneysel sonuçları daha iyi tahmin ettiği sonucuna ulaşmışlardır.

Yapılan çalışmalar incelendiğinde, silindirik kompozit elemanlara yönelik araştırmaların çoğunluğunun ya iki eksenli yorulma ya da iç basınç-sıcaklık koşullarında olduğu görülmüştür. Çalışmaların bir kısmında ise burkulma-sıcaklık, iç basınç-eksenel, eksenel-kayma, eksenel-transvers yüklemeleri göz önüne alınmıştır. Ancak bu çalışmalarda sıcaklık ikinci bir yük olarak hesaba katılmıştır. Bu araştırmada ise çevresel şartlar ayrı parametre olarak düşünülerek iki eksenli pozitif ve/veya negatif düzlemsel yayılı yüklerin ve kayma yüklerinin etkisini göz önüne alan hasar zarfları ile kompozit malzemelerin dayanımı araştırılmıştır. Araştırma hem açılı hem de çapraz katlı simetrik, dengeli S-cam lifi/epoksi ve karbon lifi/epoksi tabakalı kompozitlerin iki eksenli yüklemelerini kapsamaktadır. Kompozit malzemelerin hasar durumu ESAComp programı vasıtasıyla Tsai-Wu ve Puck ölçütlerine göre analiz edilmiş ve böylece iki farklı hasar ölçütü karşılaştırılmıştır.

\section{MATERYAL VE METOT}

Analizler için tek yönlü karbon lifi/epoksi ve Scam lifi/epoksi ile çapraz ve açılı katlı tabakalı kompozitler tasarlanmıştır. Karbon lifi/epoksi (TORAY T700GC) ve S-cam lifi/epoksi (Cycom 381-S2) kompozit malzemelerin mekanik özellikleri Çizelge 1'de verilmiştir. Seçilen kompozit malzemelerin mekanik özellikleri üç farklı ortam sıcaklığında ve hem sicaklığın hem de nemin bulunduğu çevresel şartlar için verilmiştir. TORAY T700GC için $-54{ }^{\circ} \mathrm{C}, 24{ }^{\circ} \mathrm{C}, 84{ }^{\circ} \mathrm{C}$ ortam sicaklıkları ve $84{ }^{\circ} \mathrm{C}$ ortam sicaklığ 1 ile ortamda bulunan $\% 70$ bağıl nemin neden olduğu ağırlıkça $\% 1$ nem miktarı ele alınmıştır. Cycom 381-S2 için ise $-54{ }^{\circ} \mathrm{C}, 22{ }^{\circ} \mathrm{C}, 82{ }^{\circ} \mathrm{C}$ ortam sicaklığ 1 değerleri ve $71{ }^{\circ} \mathrm{C}$ ortam sicaklığ 1 ile ortamda bulunan $\% 100$ bağıl nemin neden olduğu ağırlıkça \%1,5 nem miktarı ele alınmıştır. Çapraz katlı kompozit malzemeler için $\left[\left(0_{2} / 90_{2}\right)_{2}\right]_{\mathrm{s}}$ dizilimi, aç11 katlı kompozit malzemeler için $\left[00_{2} / 45_{2} / 90_{2} /-45_{2}\right]_{\mathrm{s}}$ dizilimi kullanılmıştır. Simetrik dizilim ile tasarlanan kompozit malzemelerde hem 1 ve 2 yönlerindeki yayılı yükler altındaki hasar durumu hem de 1 yönündeki yayılı yük ve 1-2 düzlemindeki kayma yükü altındaki hasar durumu araştırılmıştır. Tabakalı kompozit malzemelerin hasarı; etkileşimsiz (non-interactive) hasar ölçütleri (Maksimum gerilme, Maksimum gerinim, Maksimum kayma gerilmesi), etkileşimli (interactive) hasar ölçütleri (Tsai-Wu, Tsai-Hill, Hoffman) ve hasar biçimi ile ilişkili hasar ölçütleri (Hashin, Puck, Chang-Chang) ile incelenmektedir. $\mathrm{Bu}$ çalışmada tasarlanan kompozit malzemelerin iki eksenli yükleme altındaki hasarları hem TsaiWu hem de Puck hasar ölçütüne göre tespit edilmiştir. 
Çizelge 1. Analizlerde kullanılan karbon lifi/epoksi ve S-cam lifi/epoksi kompozit malzemelerin mekanik özellikleri [15,16]

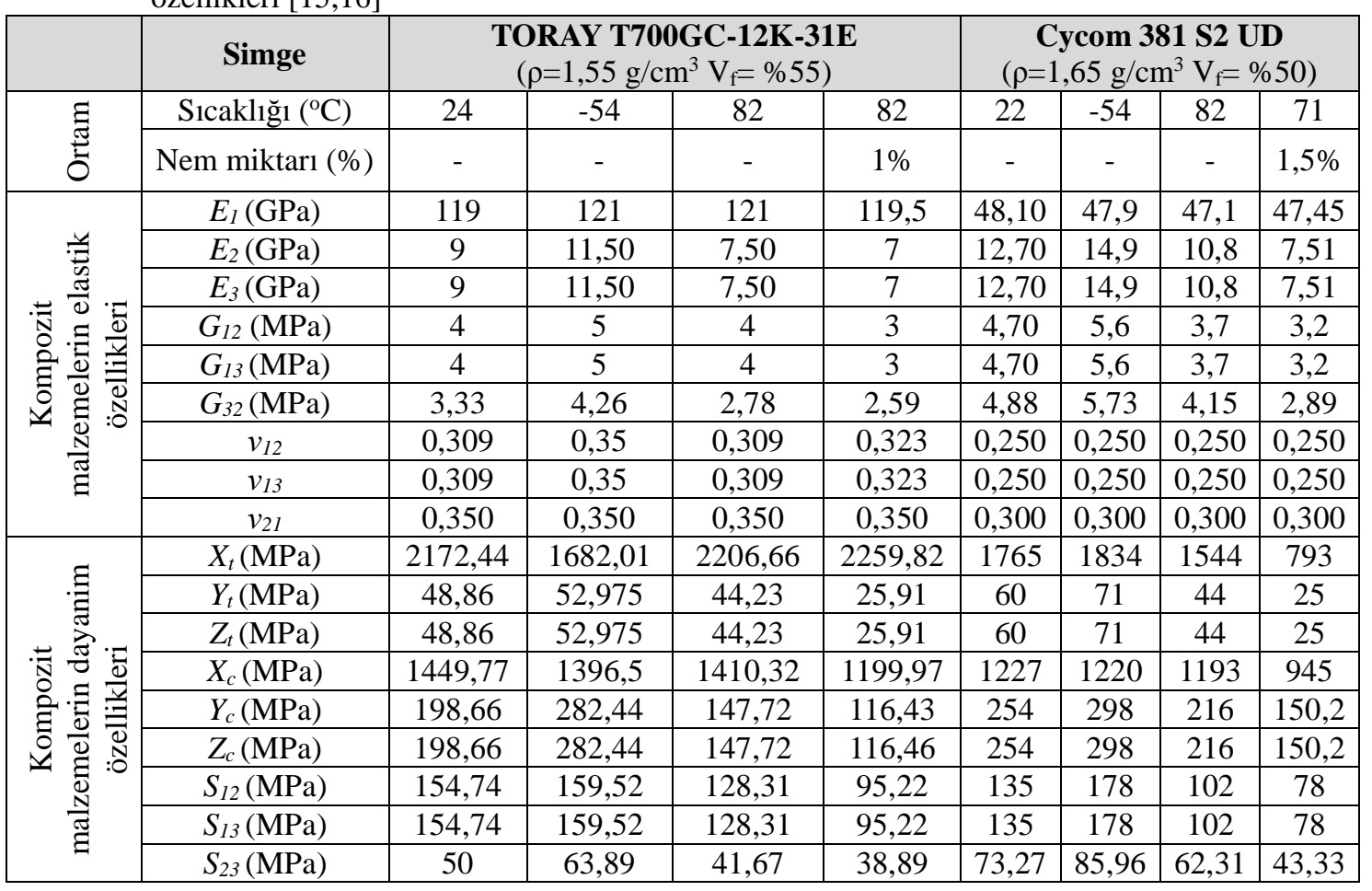
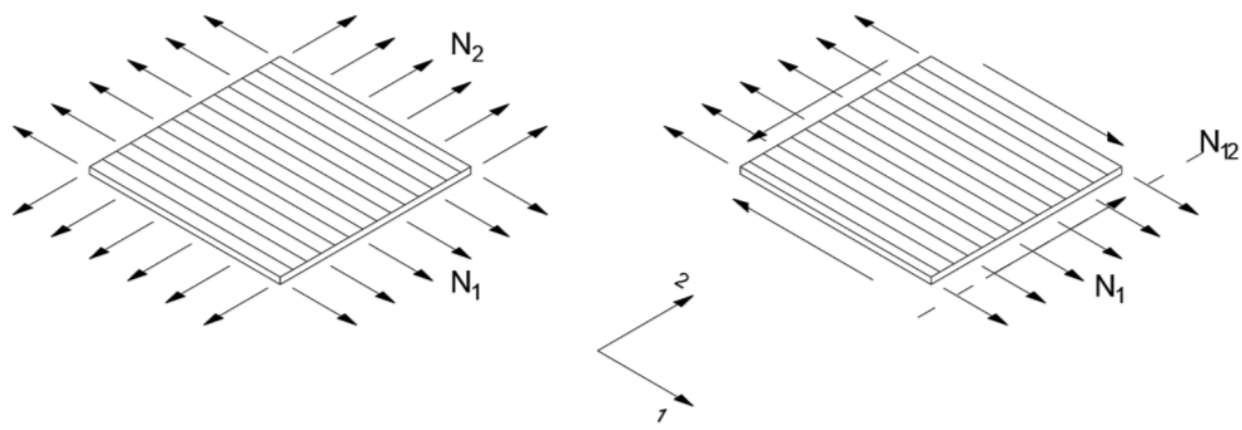

Şekil 1. Tabakalı kompozit malzemelerin iki eksenli yükleme durumları

Tsai-Wu hasar ölçütüne göre kompozit malzemenin hasara uğramaması için Eşitlik 1 ile hesaplanan $f$ değeri 1 'den küçük olmalıdır. Tabakalı kompozit yapıyı oluşturan tabakalardan herhangi birinde $f$ değerinin 1 'e eşit veya büyük olması gerek ve yeter şart olarak kabul edilerek tasarlanan modeller için bu şartı sağlayan yük değerleri tespit edilmiştir. Eşitlik 1 'de $\sigma_{1}$ ve $\sigma_{2}$ ifadeleri sırasıyla 1 ve 2 yönlerindeki eksenel gerilme değerlerini, $\tau_{12}$ ifadesi 1-2 düzlemindeki kayma gerilmesini ifade eder. Diğer katsayılar ise 1 ve 2 yönlerindeki çekme dayanımlarına $\left(X_{t}, Y_{t}\right)$, basma dayanımlarına $\left(X_{c}, Y_{c}\right)$ ve kayma dayanımına (S) bağlı sabitlerdir.

$f=F_{1} \sigma_{1}+F_{2} \sigma_{2}+F_{6} \tau_{12}+2 F_{12} \sigma_{1} \sigma_{2}+F_{11} \sigma_{1}^{2}+F_{22} \sigma_{2}^{2}+F_{66} \tau_{12}^{2}$

$\mathrm{F}_{1}=\frac{1}{\mathrm{X}_{\mathrm{t}}}-\frac{1}{\mathrm{X}_{\mathrm{c}}}, \quad \mathrm{F}_{2}=\frac{1}{\mathrm{Y}_{\mathrm{t}}}-\frac{1}{\mathrm{Y}_{\mathrm{c}}}, \quad \mathrm{F}_{6}=0$ 


$$
\mathrm{F}_{11}=\frac{1}{\mathrm{X}_{\mathrm{t}} \mathrm{X}_{\mathrm{c}}}, \quad \mathrm{F}_{22}=\frac{1}{\mathrm{Y}_{\mathrm{t}} \mathrm{Y}_{\mathrm{c}}}, \quad \mathrm{F}_{66}=\frac{1}{\mathrm{~S}^{2}}
$$

Puck ölçütü, takviye lif hasarını (FF) ve matris malzeme hasarını (MF) ayrı ayrı ele almakta ve lif hasarı ile matris hasarı için farklı indisler $\left(\mathrm{I}_{\mathrm{FF}}, \mathrm{I}_{\mathrm{MF}}\right)$ kullanmaktadır. Takviye lif hasarı yalnız lif doğrultusundaki çekme yükü altında oluşmaktadır. Matris malzeme hasarı için ise üç farklı kırılma biçimi esas alınmaktadır (Şekil 2). Ölçüte göre Mod A hasarında takviye liflere dik yönde, yani malzemeye enine etkileyen çekme kuvvetleri ile takviye lifler arasında matris çatlakları oluşmaktadır. Mod B hasarında düzlem kayma gerilmeleri ile küçük basma gerilmeleri altında malzemede takviye lifler arasında matris çatlakları oluşmaktadır. Mod C hasarında ise basma yükleri altında malzemede eğik düzlemler boyunca matris çatlakları oluşmaktadır. Her bir hasar modunu kontrol etmek için Eşitlik 2-6 kullanılmaktadır. Puck ve Schürmann'a göre (2004) tabakalı kompozit malzemelerin hasar analizleri için; herbir katmanın gerilme ve gerinim analizleri, kırılma ölçütleri ve hasar ile indirgenmiş dayanımlarına ihtiyaç duyulmaktadır. $\mathrm{Bu}$ detaylı analizler gerçekleştirilebilirse en gerçekçi hasar zarfını oluşturulabilmektedir. Ancak araştırmacılar önerdikleri hasar ölçütünde tabakalı kompozit malzemelerin yük altındaki ilk hasarları ile ortaya çıkan indirgenmiş dayanım değerlerini ihmal etmişlerdir.

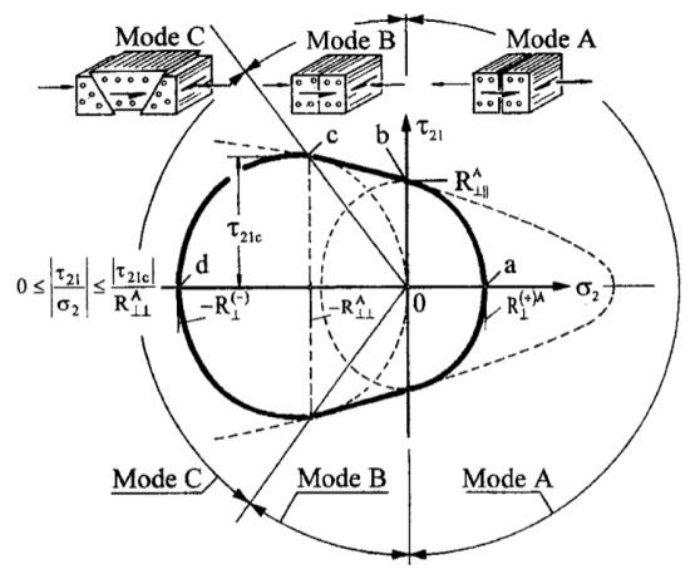

Şekil 2. Puck ölçütüne göre $\sigma_{2}$ ve $\tau_{21}$ düzlem gerilmeleri altında $\mathrm{A}, \mathrm{B}$ ve $\mathrm{C}$ hasar modlarının oluşumu [17]

$$
\begin{aligned}
& \sigma_{1}>0 \rightarrow I_{F F}=\sigma_{1} / F_{1 t} \\
& -\sigma_{1}<0 \rightarrow I_{F F}=-\sigma_{1} / F_{1 c} \\
& \sigma_{2} \geq 0 \rightarrow I_{M F, A}=\sqrt{\left(\frac{\sigma_{6}}{F_{6}}\right)^{2}+\left(1-p_{6 t} \frac{F_{2 t}}{F_{6}}\right)^{2}\left(\frac{\sigma_{2}}{F_{2 t}}\right)^{2}}+p_{6 t} \frac{\sigma_{2}}{F_{6}} \\
& \left.\mid \begin{array}{c}
\sigma_{2}<0 \\
\left|\frac{\sigma_{2}}{\sigma_{6}}\right| \leq \frac{F_{2 A}}{F_{6 A}}
\end{array}\right\} \rightarrow I_{M F, B}=\frac{1}{F_{6}}\left[\sqrt{\sigma_{6}^{2}+\left(p_{6 c} \sigma_{2}\right)^{2}}+p_{6 c} \sigma_{2}\right] \text { (5) } \\
& F_{2 A}=\frac{F_{6}}{2 p_{6 c}}\left[\sqrt{1+2 p_{6 c} \frac{F_{2 c}}{F_{6}}}-1\right] \quad p_{2 c}=p_{6 c} \frac{F_{2 A}}{F_{6}} \\
& \left.\left|\frac{\sigma_{2}}{\sigma_{6}}\right| \leq \frac{F_{2 A}}{F_{6 A}}\right\} \rightarrow I_{M F, C}=-\frac{F_{2 c}}{\sigma_{2}}\left[\left(\frac{\sigma_{6}}{2\left(1+p_{2 c}\right) F_{6}}\right)^{2}+\left(\frac{\sigma_{2}}{F_{2 c}}\right)^{2}\right]
\end{aligned}
$$

Açılı ve çapraz katlı tasarlanan karbon lifi/epoksi ve tek yönlü S-cam lifi/epoksi kompozit malzemelerin Tsai-Wu ve Puck ölçütleri ile hasar durumu, ilk katman hasarı (First Ply Failure, FPF) yaklaşımına göre değerlendirilmiştir. FPF yöntemi malzemenin hasar direncini göz önüne almakta olup, hasar toleransını göz ardı etmektedir. FPF yöntemine göre tabakalı kompozit malzemeyi oluşturan tabakalardan herhangi biri veya eş zamanlı olarak birkaçı hasara uğradığında kompozit malzemenin hasara uğradığ 1 kabul edilir. Kompozit malzemede oluşan gerilmeler klasik laminasyon teorisine göre hesaplanır.

\section{ARAŞTIRMA BULGULARI}

\subsection{S-cam Lifi/epoksi Tabakalı Kompozit Malzemelerin Analizi}

Farklı çevresel şartlarda açılı katlı olarak tasarlanmış S-cam lifi/epoksi tabakalı kompozit malzemelerin, 1 ve 2 yönlerindeki yayılı yükler ve 1 yönündeki yayılı yük ile 1-2 düzlemindeki kayma yükü altındaki hasar durumu Şekil 3 ve Şekil 4'de ayrı ayrı verilmiştir. S-cam lifi/epoksi tabakalı kompozit malzeme, $-54{ }^{\circ} \mathrm{C}$ ortam sıcaklığındaki mekanik özellikleri ile tüm yükleme 
durumları için hem Tsai-Wu hem de Puck ölçütüne göre diğer ortam sıcaklıklarına kıyasla en yüksek dayanımı göstermiştir. Puck ölçütüne göre, malzemenin bulunduğu ortam sicaklığı arttıkça tüm yükleme durumları için malzemenin dayanımı düşmektedir. Ortam neminin yükselmesi de belirgin dayanım kaybına neden olmaktadır. $71{ }^{\circ} \mathrm{C}$ ortam sicaklığında ve ağırlıkça \%1,5 nem içerisinde bulunan malzemenin dayanımı $82{ }^{\circ} \mathrm{C}$ ortam sicaklığında bulunan malzemeden daha düşüktür. Tsai-Wu ölçütüne göre de ortam sıcaklığ arttıkça malzemenin dayanım kaybı artmakta, nemin etkisi ile dayanım kaybındaki azalma daha da belirgin hale gelmektedir. Ancak $82{ }^{\circ} \mathrm{C}$ ortam sıcaklığında, her iki yönde basma (basma-basma) yüklemesi altındaki $\mathrm{S}$-cam lifi/epoksi tabakalı kompozit malzemede en yüksek $\mathrm{N}_{1}$ ve $\mathrm{N}_{2}$ değerleri için malzeme dayanımı en düşük seviyededir. 1 ve 2 yönlerinde ayrı ayrı tekil basma yükleri altında Tsai-Wu ölçütü daha güvenli davranış göstermektedir. Çekme-basma ve basma-çekme halindeki iki eksenli yüklerde de Tsai-Wu daha güvenli hasar zarfları oluşturmaktadır. Ancak hem her iki yönde çekme (çekme-çekme) hem de her iki yönde basma yüklerinin en yüksek değerleri için Puck ölçütüne göre oluşturulan hasar zarfları Tsai-Wu ölçütüne göre daha güvenlidir. Çizelge 1'de verilen mekanik özelliklere göre ortamda bulunan nemin etkisi ile S-cam lifi/epoksi kompozit malzemenin basma yönündeki mekanik özellikleri en düşük değerlere sahip olurken, Tsai$\mathrm{Wu}$ ölçütü belirtilen çevresel şartlarda basmabasma yükü altında bu malzeme ile üretilmiş açılı katlı tabakalı kompozitin $82{ }^{\circ} \mathrm{C}$ ortam sıcaklığındaki aynı malzemeye göre daha dayanıklı olduğunu belirlemiştir. Bu durum Puck ölçütünün Tsai-Wu ölçütüne göre iki eksenli basma yükü altında daha gerçekçi sonuç verdiğini göstermektedir.

a)
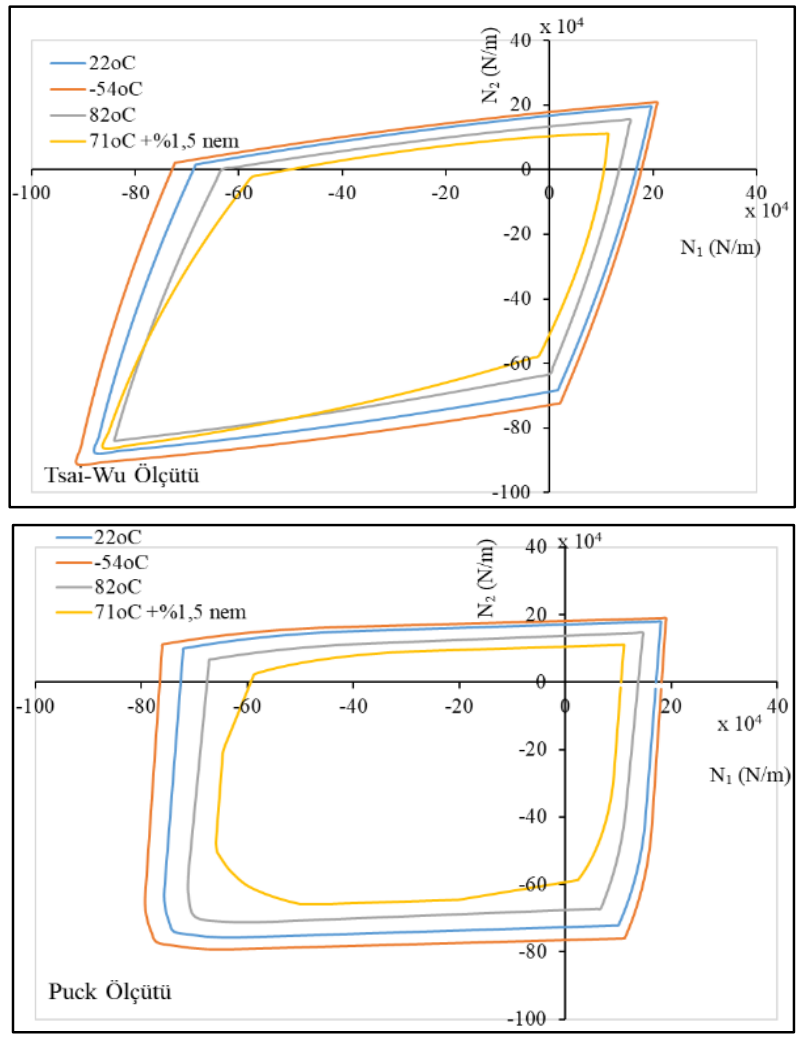

Şekil 3. Açılı katlı S-cam lifi/epoksi tabakalı kompozit malzemelerin $\mathrm{N}_{1}$ ve $\mathrm{N}_{2}$ yayılı yükleri altında a) Tsai-Wu ölçütüne, b) Puck ölçütüne göre hasar zarfları 
Açılı katlı S-cam lifi/epoksi malzemenin $\mathrm{N}_{1}$ ile $\mathrm{N}_{12}$ yükü altında dayanımı ortam sıcaklığının artması ile azalmaktadır. Ortamda nem olması halinde dayanım kaybı daha belirgin hale gelmektedir. $\mathrm{N}_{1}$ ile $\mathrm{N}_{12}$ yükü altında Tsai-Wu hasar ölçütü tüm ortam şartları için daha emniyetli dayanım değerleri tespit etmektedir. $\mathrm{N}_{1}$ yükünün hem pozitif hem negatif değerleri ile birlikte uygulanan ve malzemeyi hasara uğratan $\mathrm{N}_{12}$ değeri Tsai-Wu ölçütüne göre Puck ölçütü ile hesaplanan değerden daha düşüktür. Özellikle ortamda nem bulunması halinde Tsai-Wu ölçütüne göre malzemenin dayanımı belirgin olarak düşmektedir.

a)
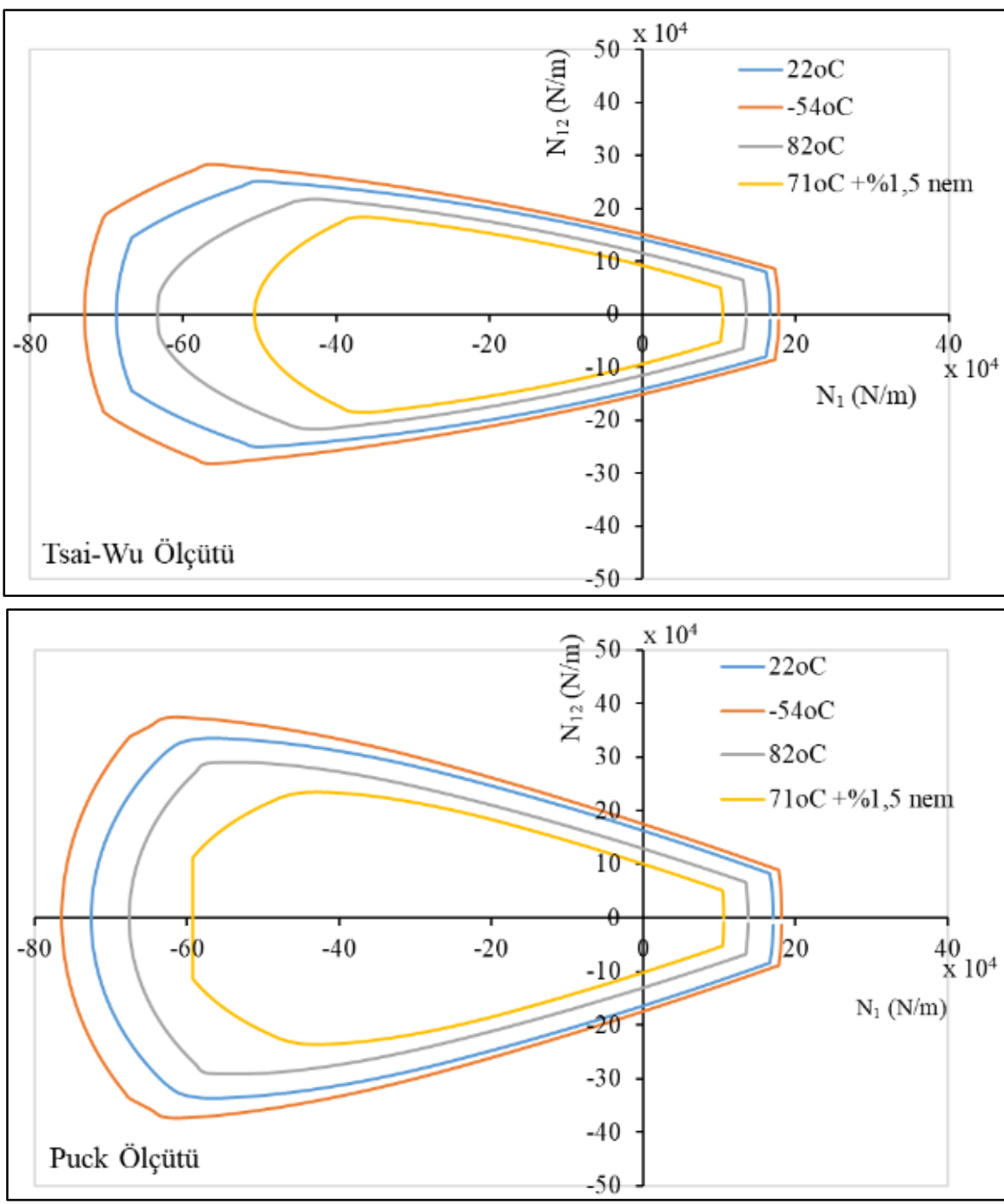

Şekil 4. Açılı katlı S-cam lifi/epoksi tabakalı kompozit malzemelerin $\mathrm{N}_{1}$ ve $\mathrm{N}_{12}$ yayılı yükleri altında a) Tsai-Wu ölçütüne, b) Puck ölçütüne göre hasar zarfları

Çapraz katlı S-cam lifi/epoksi tabakalı kompozit malzemelerin $\mathrm{N}_{1}$ ve $\mathrm{N}_{2}$ yükleri için elde edilen hasar zarflarına göre basma-basma ve çekme- çekme yükleri altında Puck ölçütü daha güvenli sonuçlar vermektedir (Şekil 5a ve b). Yüksek sicaklıklarda basma-çekme ve çekme-basma 
yükleri için Tsai-Wu ölçütü ile hesaplanan yük değerleri daha güvenlidir. $-54{ }^{\circ} \mathrm{C}$ ve $22{ }^{\circ} \mathrm{C}$ ortam sicaklığında çekme-çekme, basma-çekme ve çekme-basma yükleri ile yapılan analizlerde, çapraz katlı malzeme hem Tsai-Wu hem de Puck ölçütüne göre yaklaşı aynı dayanımı göstermektedir. Açılı katlı S-cam lifi/epoksi kompozitlere benzer şekilde, çapraz katlı kompozitlerde de ortam nemi belirgin olarak malzemenin dayanımını düşürmektedir. Puck ölçütü ortam sıcaklığı ve nemi etkisine karşı daha duyarlı davranış göstermekte ve daha güvenli davranmaktadır. Çapraz katlı S-cam lifi/epoksi tabakalı kompozit malzemelerin $\mathrm{N}_{1}$ ve $\mathrm{N}_{12}$ yükleri için Tsai-Wu ve Puck ölçütüne göre elde edilen hasar zarfları ise oldukça benzerdir. Tüm iki eksenli yükleme koşulları için Puck ve Tsai-Wu ölçütü her bir ortam sıcaklığında yaklaşık aynı hasar zarflarını oluşturmaktadır.

a)

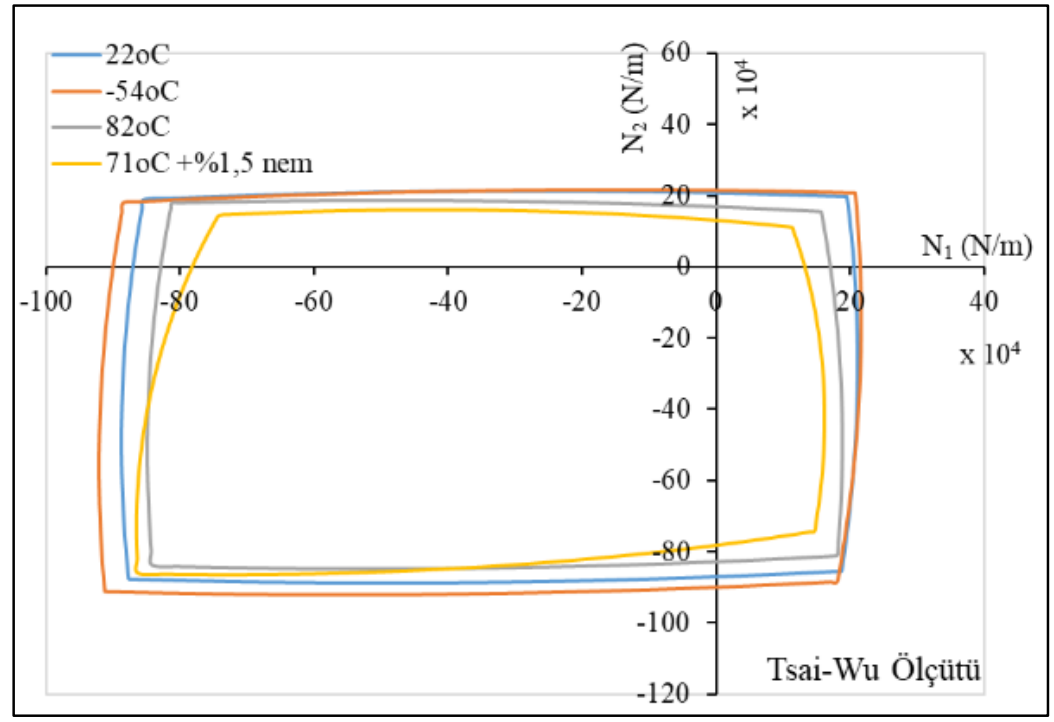

b)

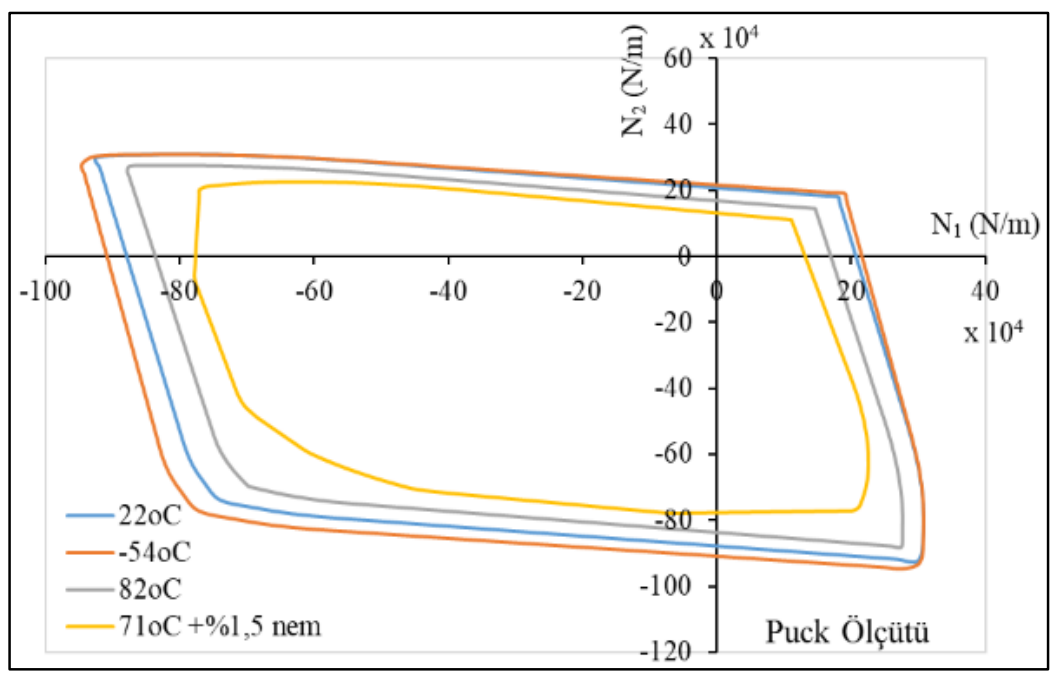

Şekil 5. Çapraz katlı S-cam lifi/epoksi tabakalı kompozit malzemelerin $\mathrm{N}_{1}$ ve $\mathrm{N}_{2}$ yayılı yükleri altında a) Tsai-Wu ölçütüne, b) Puck ölçütüne göre hasar zarfları 


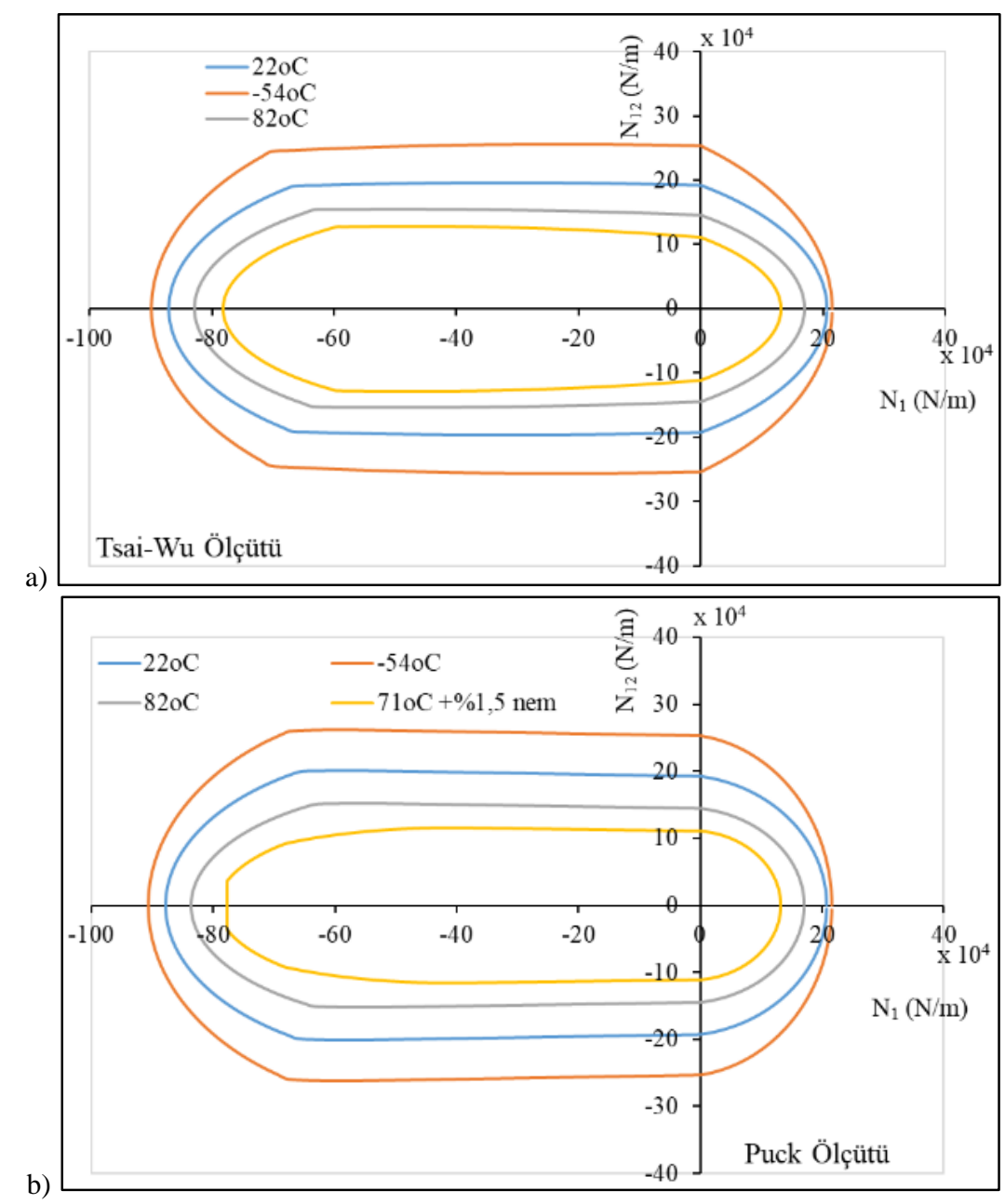

Şekil 6. Çapraz katlı S-cam lifi/epoksi tabakalı kompozit malzemelerin $\mathrm{N}_{1}$ ve $\mathrm{N}_{12}$ yayılı yükleri altında a) Tsai-Wu ölçütüne, b) Puck ölçütüne göre hasar zarfları

\subsection{Karbon Lifi/Epoksi Tabakalı Kompozit} Malzemelerin Analizi

$\mathrm{N}_{1}$ ve $\mathrm{N}_{2}$ yükleri altındaki açılı katlı karbon lifi/epoksi malzeme için Tsai-Wu ve Puck ölçütleri ile elde edilen hasar zarfları oldukça farklıdır (Şekil 7a ve b). Tsai-Wu ölçütü, basma-basma yükü altındaki açılı katlı karbon lifi/epoksi malzeme için Puck ölçütüne göre oldukça yüksek dayanım değerleri hesaplamaktadır. İki hasar ölçütü arasındaki bu belirgin fark, Puck ölçütünün tabakalı kompozit malzemede hasar mekanizmasını, biri lif hasarı üçü matris malzeme hasarı olmak üzere, dört farklı mekanizma ile incelemesinin bir sonucudur. Karbon lifi/epoksi malzemede, takviye lifin ve matris malzemenin dayanımları arasındaki farkın, S-cam lifi/epoksi tabakalı kompozit malzemedeki bileşenlerin dayanımları arasındaki farka oranla daha yüksek olması da bu sonuca katkı sağlamaktadır. Çekmeçekme durumuna göre yüklerin maksimum değeri için Tsai-Wu ölçütü daha yüksek dayanım değerleri hesaplamaktadır. Çekme-basma ve basma-çekme yükleri için de Puck ölçütü ile tespit edilen dayanım değerleri daha yüksektir.

Açılı katlı karbon lifi/epoksi malzemenin ortam sıcaklığına bağlı dayanımı incelendiğinde Tsai-Wu 
ölçütünün sıcaklık değişimine karşı daha duyarlı olduğu görülmüştür. Ortam sıcaklığının artması ile Tsai-Wu ölçütüne göre özellikle basma-basma ve çekme-çekme yükleri altında kompozit malzemenin dayanımı hızlı bir şekilde azalmıştır. Çekme-basma ve basma-çekme yükleri altında ise ortam sıcaklığının etkisi yok denecek kadar azken ortam neminin etkisi belirgindir. Puck ölçütüne göre çekme-çekme yüklemesi için ortam sıcaklığının artması ile malzeme dayanımı artmaktadır. Puck ölçütü, Tsai-Wu ölçütüne kıyasla ortam sıcaklığının değiş̧imine karşı daha az duyarlı sonuçlar vermektedir. Bununla birlikte Puck ölçütü, ortam neminin artması ile malzeme dayanımının belirgin olarak düștüğünü tespit etmektedir. Her iki hasar ölçütüne göre $\mathrm{N}_{1}$ ve $\mathrm{N}_{2}$ yükleri; çekme halindeyken en yüksek dayanımın $82{ }^{\circ} \mathrm{C}$ ortam sicaklığında, basma halindeyken en yüksek dayanımın $-54 \quad{ }^{\circ} \mathrm{C}$ ortam sicaklığında olduğu tespit edilmiştir. $\mathrm{N}_{1}$ ve $\mathrm{N}_{12}$ yükleri altındaki açılı katlı karbon lifi/epoksi kompozit malzeme için Tsai-Wu daha emniyetli hasar zarfları oluşturmaktadır (Şekil 8a ve b). Ancak $-54{ }^{\circ} \mathrm{C}$ ortam sicaklığında $\mathrm{N}_{1}$ yükünün negatif olduğu ve $\mathrm{N}_{12}$ yükünün sıfıra yakın olduğu yükleme hali istisna oluşturmakta ve Puck ölçütü daha emniyetli davranış göstermektedir.

a)
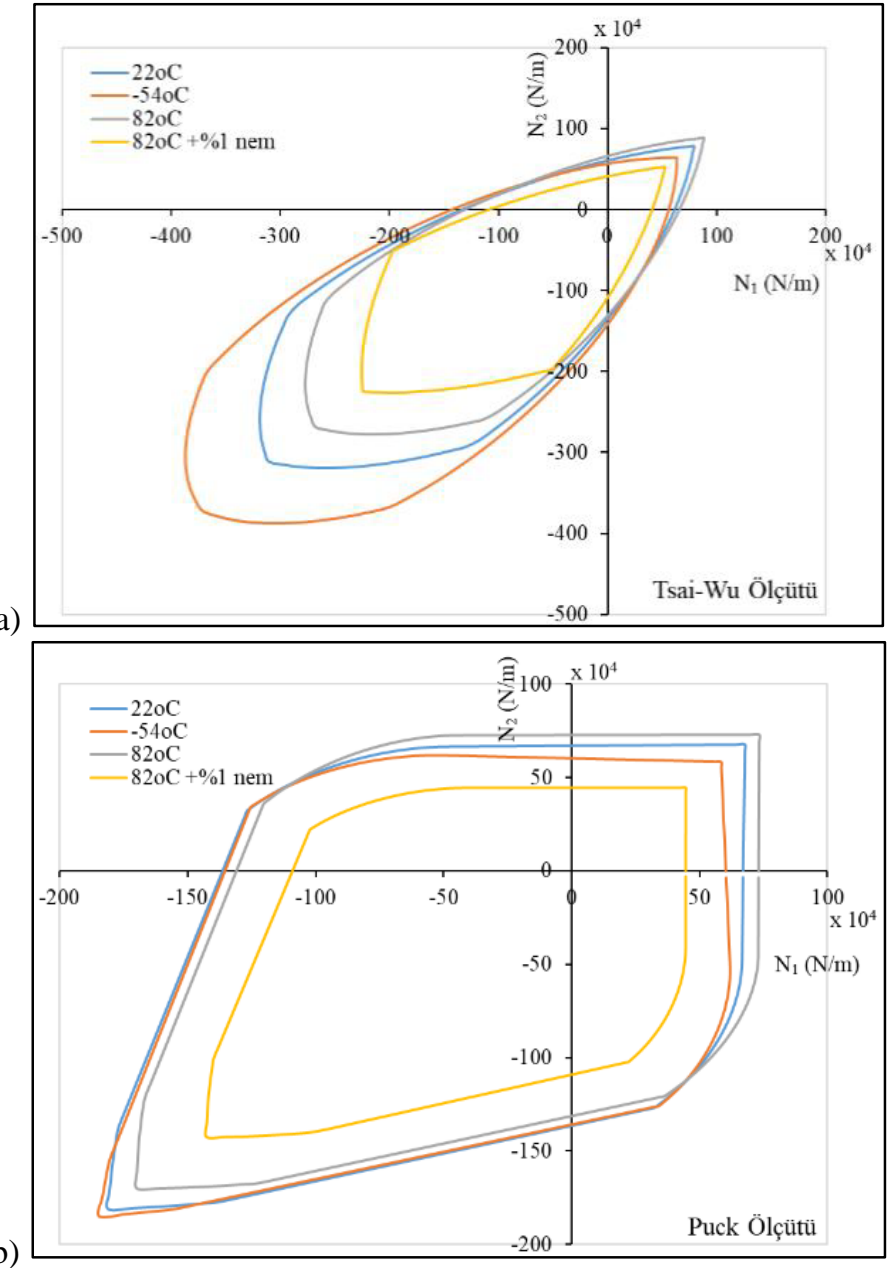

Şekil 7. Açılı katlı karbon lifi/epoksi tabakalı kompozit malzemelerin $\mathrm{N}_{1}$ ve $\mathrm{N}_{2}$ yayılı yükleri altında a) Tsai-Wu ölçütüne, b) Puck ölçütüne göre hasar zarfları 


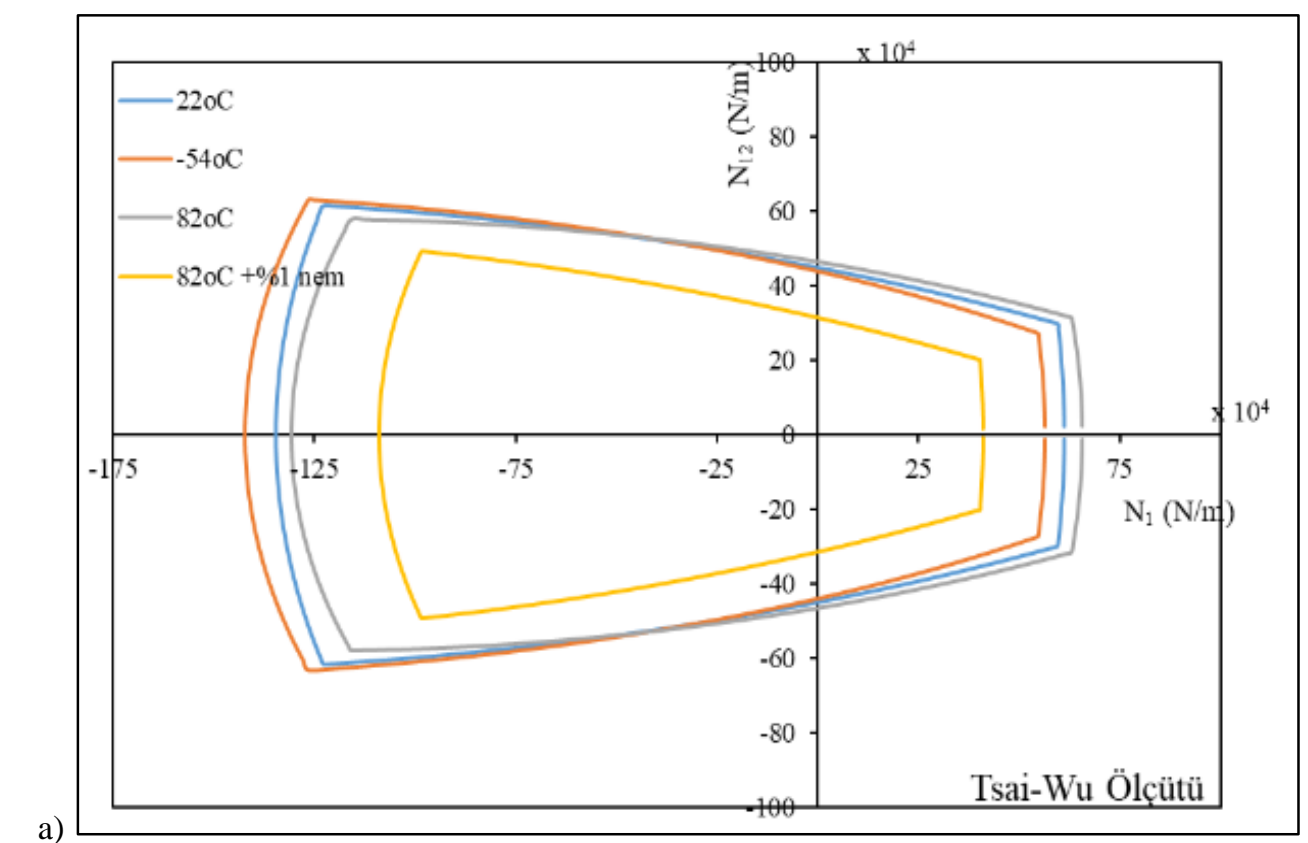

a)

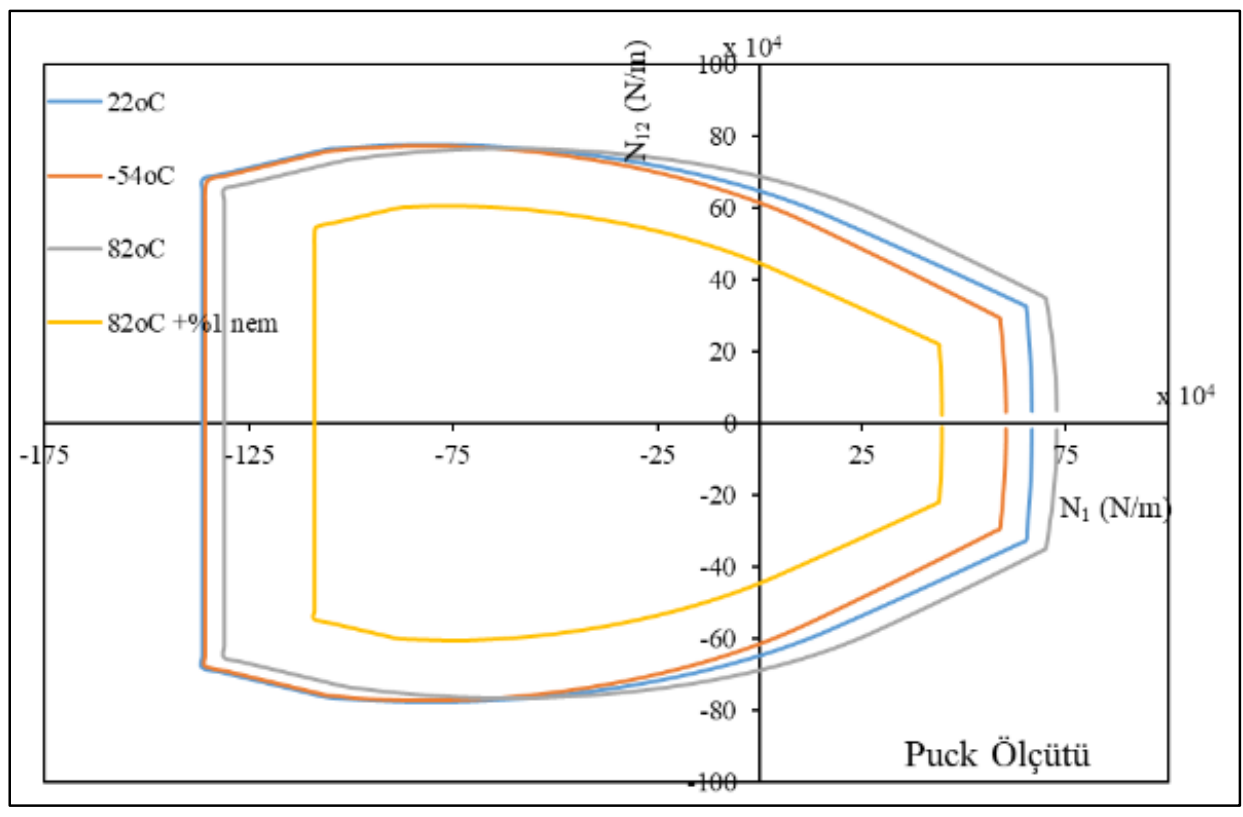

Şekil 8. Açılı katlı karbon lifi/epoksi tabakalı kompozit malzemelerin $\mathrm{N}_{1}$ ve $\mathrm{N}_{12}$ yayılı yükleri altında, a) Tsai-Wu ölçütüne, b) Puck ölçütüne göre hasar zarfları

Çapraz katlı karbon lifi/epoksi malzemenin $\mathrm{N}_{1}$ ve $\mathrm{N}_{2}$ yükleri altında Tsai-Wu ve Puck ölçütüne göre elde edilen hasar zarflarının ortam şartlarına göre değişimi açılı katlı karbon lifi/epoksi malzeme için ortaya çıkan değişime benzerdir. Tsai-Wu ölçütüne göre basma-basma yükleri altında ortam sıcaklığının artması ile hasar zarfı küçülmekte, ortam neminin artması ile malzeme dayanımı en aza inmektedir. Çekme-çekme yükleri altında ise tam tersi sicaklığın etkisi ile dayanım artmakta 
ancak ortamda bulunan nem malzemenin dayanımını yine en aza indirmektedir. Tsai- $\mathrm{Wu}$ ölçütü basma-basma yükleri için tüm çevresel şartlarda Puck ölçütüne kıyasla oldukça yüksek dayanım değerleri hesaplamakta, çekme-basma ve basma-çekme yükleri için ise daha düşük dayanım yükleri tespit etmektedir. Farklı çevresel şartlar altındaki çekme-çekme yükleri için ise Tsai-Wu ve Puck ölçütü birbirlerine yakın dayanım değerleri göstermektedir.

a)

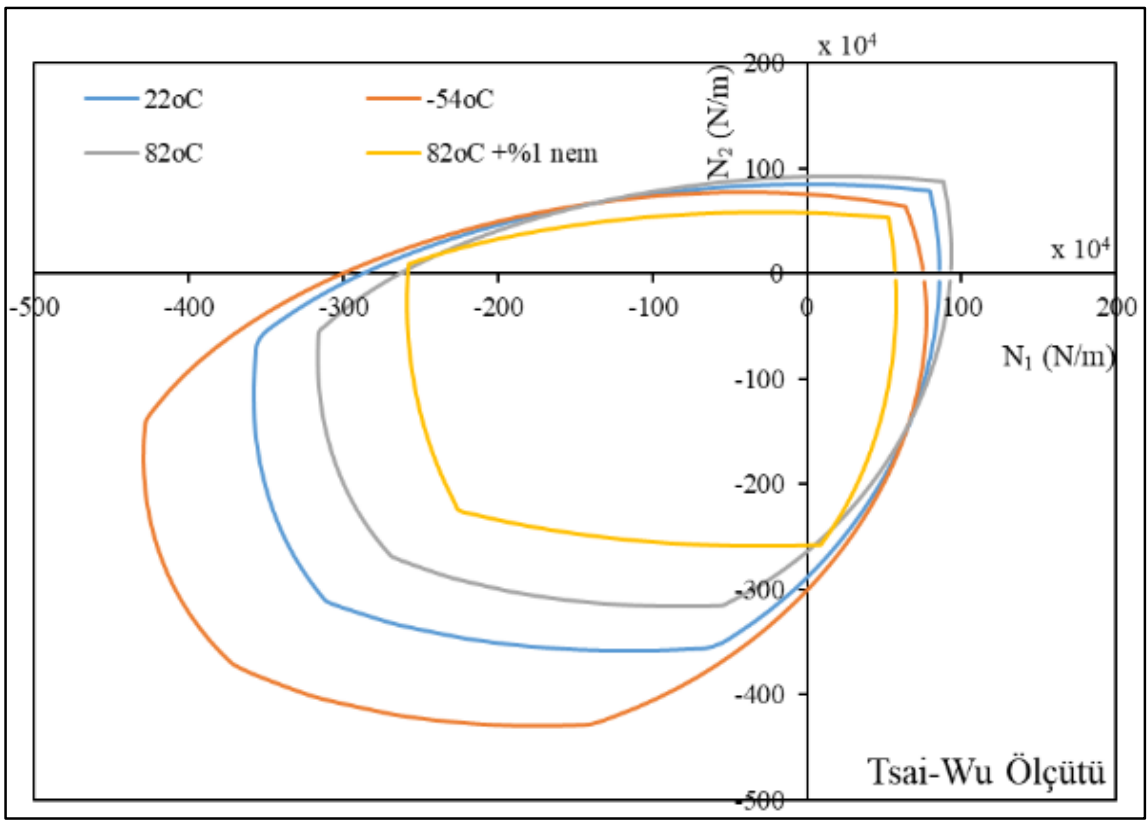

b)

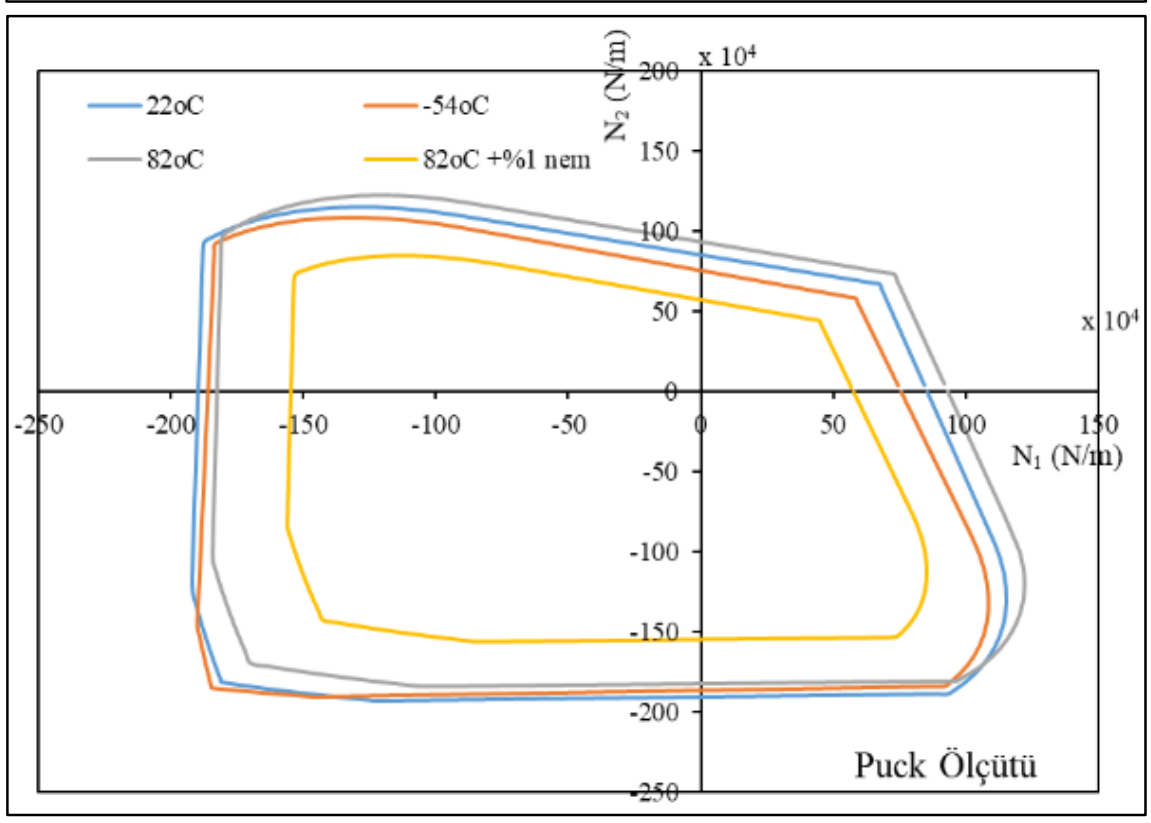

Şekil 9. Çapraz katlı karbon lifi/epoksi tabakalı kompozit malzemelerin $\mathrm{N}_{1}$ ve $\mathrm{N}_{2}$ yayılı yükleri altında a) Tsai-Wu ölçütüne, b) Puck ölçütüne göre hasar zarfları 
a)

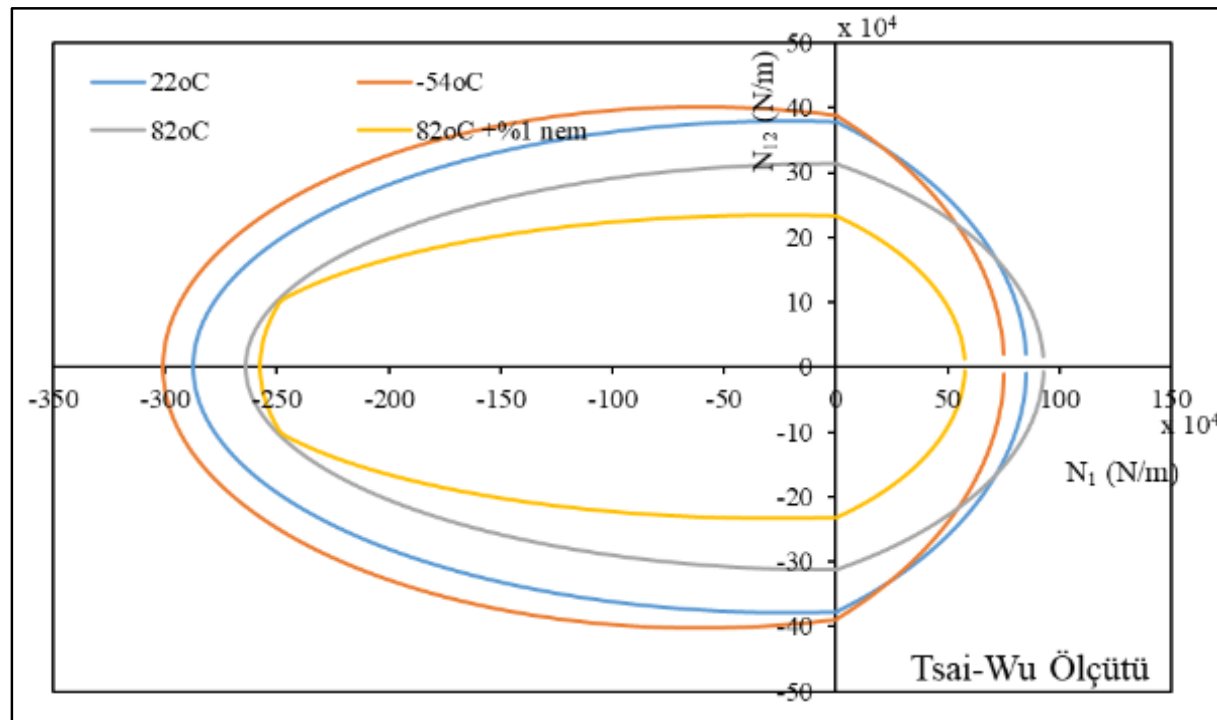

b)

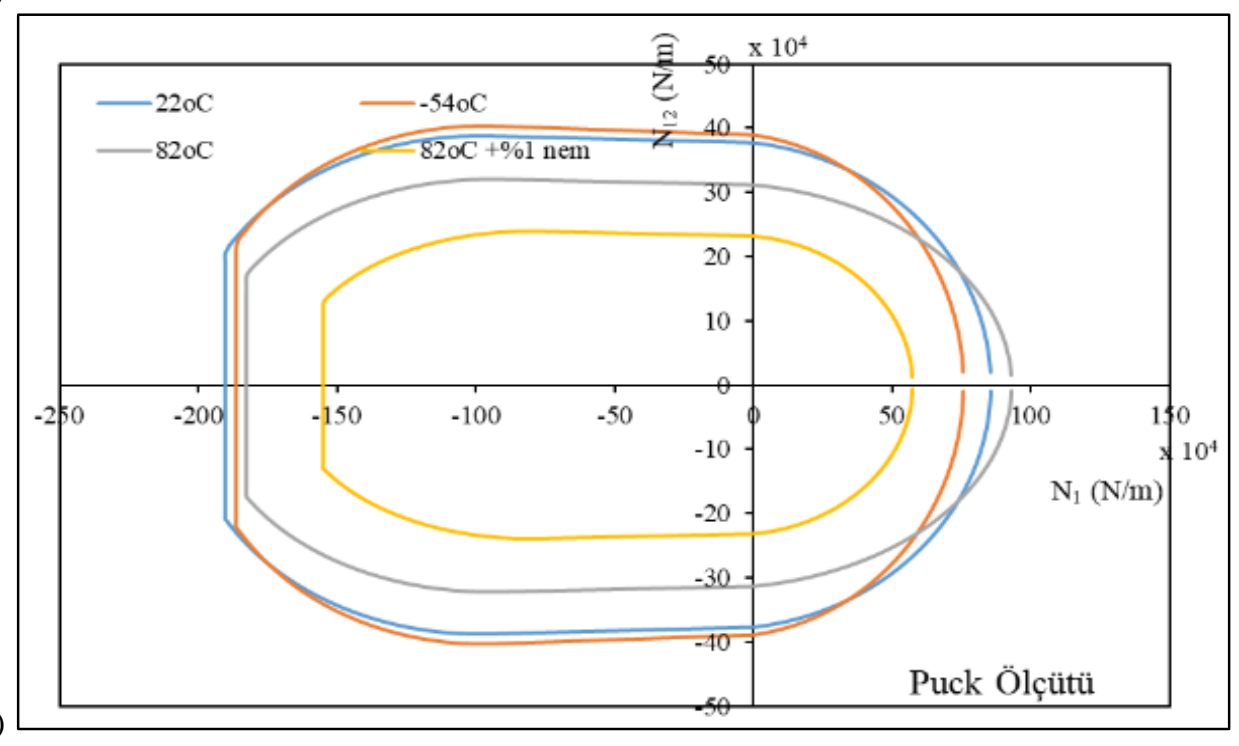

Şekil 10. Çapraz katlı karbon lifi/epoksi tabakalı kompozit malzemelerin $\mathrm{N}_{1}$ ve $\mathrm{N}_{12}$ yayılı yükleri altında a) Tsai-Wu ölçütüne, b) Puck ölçütüne göre hasar zarfları

$\mathrm{N}_{1}$ ve $\mathrm{N}_{12}$ yükleri altındaki çapraz katlı karbon lifi/epoksi kompozit malzemenin dayanımı, hem Tsai-Wu hem de Puck ölçütüne göre $\mathrm{N}_{1}$ yükünün maksimum pozitif değerleri için ortam sicaklı̆̆ yükseldikçe artmaktadır. $\mathrm{N}_{1}$ yükünün negatif değerleri için de ortam sicaklığı düştükçe malzemenin dayanımı artmaktadır. Çevresel şartların malzemenin dayanımı üzerindeki etkisi her iki hasar ölçütüne göre benzerdir. Ancak Puck ölçütü $\mathrm{N}_{1}$ yükünün negatif olduğu tüm çevresel şartlarda iki eksenli yükleme hali için Tsai-Wu ölçütüne göre çok daha fazla emniyetli hasar zarfları oluşturmaktadır.

\section{SONUÇLAR}

Aç1lı ve çapraz katlı S-cam lifi/epoksi ve karbon lifi/epoksi tabakalı kompozit malzemelerin iki 
eksenli yükler altında hasar zarfları oluşturulmuştur. Tabakalı kompozit malzemelerin farklı çevresel şartlarda elde edilen mekanik özellikleri kullanılmıştır. Hasar zarfları Tsai-Wu ve Puck hasar ölçütü kullanılarak incelenmiştir. Yüklemenin türüne, ortam sicaklı̆̆ına, malzeme tipine ve takviye liflerin yerleşim açısına bağlı olarak Tsai-Wu ve Puck ölçütlerinin gösterdiği davranış değişmektedir.

İki eksenli yüklemeye maruz S-cam lifi/epoksi tabakalı kompozit malzeme için Tsai-Wu ve Puck ölçütü ile oluşturulan hasar zarfları karşılaştırıldığında;

- Hasar zarflarından daha güvenli olanın, kompozit malzemenin açılı veya çapraz katlı olmasına ve/veya uygulanan yüklerin yönüne göre değișebildiği,

- Ortam sicaklığı arttıkça malzemenin dayanımının azaldığı,

- Ortamda nem bulunmasının tüm yükleme halleri için malzeme dayanımını belirgin olarak düşürdüğü çıkarımları yapılmıştır.

İki eksenli yüklemeye maruz karbon lifi/epoksi tabakalı kompozit malzeme için Tsai-Wu ve Puck ölçütü ile oluşturulan hasar zarfları karşılaştırıldığgnda ise;

- Hem açılı hem de çapraz katlı kompozit malzemede, tüm çevresel şartlar için $\mathrm{N}_{1}$ ve $\mathrm{N}_{2}$ yüklerinin işaretlerinin aynı olması halinde Puck ölçütünün güvenli olduğu, işaretlerin farklı olması halinde Tsai-Wu ölçütünün daha güvenli olduğu,

- $\mathrm{N}_{1}$ ve $\mathrm{N}_{12}$ yükleri altında ise malzeme açılı katlı ise Tsai-Wu ölçütünün daha güvenli hasar zarfları oluştururken, malzeme çapraz katlı ise Puck ölçütünün daha güvenli hasar zarfları oluşturduğu,

- Çapraz katli malzemenin $\mathrm{N}_{1}$ ve $\mathrm{N}_{12}$ yüklemeleri altındaki dayanımının, aynı yük koşullarındaki açılı katlı malzemenin dayanımına göre ortam sıcaklığından daha az etkilendiği,

- S-cam lifi/epoksi kompozit malzemeye benzer şekilde ortam nemi karbon lifi/epoksi malzemenin de dayanımını azalttığı çıkarımları yapılmıştır.

\section{TEŞEKKÜR}

Altair ESAComp yazılımını biz araştırmacıların kullanımına sunan Altair Engineering'e teşekkür ederiz.

\section{KAYNAKLAR}

1. Abdul Majid, M.S., Assaleh, T.A., Gibson, A.G., Hale, J.M., Fahrer, A., Rookus, C.A.P., Hekman, M., 2011. Ultimate Elastic Wall Stress (UEWS) Test of Glass Fibre Reinforced Epoxy (GRE) Pipe. Compos Part A Appl Sci Manuf 42(10), 1500-1508. doi:10.1016/j. compositesa.2011.07.001.

2. Hawa, A., Abdul Majid, M.S., Afendi, M., Marzuki, H.F.A., Amin, N.A.M., Mat, F., Gibson, A.G., 2016. Burst Strength and Impact Behaviour of Hydrothermally Aged Glass Fibre/epoxy Composite Pipes. Mater Des, 89, 455-464. doi:10.1016/j.matdes.2015.09.082.

3. Yu, K., Morozov, E.V., Ashraf, M.A., Shankar, K., 2015. Numerical Analysis of the Mechanical Behaviour of Reinforced Thermoplastic Pipes Under Combined External Pressure and Bending. Compos Struct, 131, 453-61. doi:10.1016/j.compstruct. 2015.05.033.

4. Quaresimin, M., Carraro, P.A., Maragoni, L., 2015. Influence of Load Ratio on the Biaxial Fatigue Behaviour and Damage Evolution in Glass/epoxy Tubes Under Tension-torsion Loading. Compos Part A Appl Sci Manuf, 78, 294-302. doi:10.1016/j.compositesa.2015. 08.009 .

5. Perillo, G., Vacher, R., Grytten, F., Sørbø, S., Delhaye, V., 2014. Material Characterisation and Failure Envelope Evaluation of Filament Wound GFRP and CFRP Composite Tubes. Polym Test, 40:54-62. doi:10.1016/j. polymertesting.2014.08.009.

6. Quaresimin, M., Carraro, P.A., 2013. On the Investigation of the Biaxial Fatigue Behaviour of Unidirectional Composites. Compos Part B Eng, 54, 200-208. doi:10.1016/j.compositesb. 2013.05.014.

7. Reddy, P.S.K., Krishna, T.H., 2012. Optimum Design and Analysis of Filament Wound 
Composite Tubes in Pure and Combined Loading, 1, 1-4.

8. Bakaiyan, H., Hosseini, H., Ameri, E., 2009. Analysis of Multi-layered Filament-wound Composite Pipes Under Combined Internal Pressure and Thermomechanical Loading with Thermal Variations. Compos Struct, 88, 532-541. doi:10.1016/j.compstruct.2008.05. 017.

9. Çallioğlu, H., Ergun, E., Demirdag, O., 2008. Stress Analysis of Filament-wound Composite Cylinders Under Combined Internal Pressure and Thermal Loading. Adv Compos Lett 17, 13-21. doi:10.1177/096369350801700102.

10. Li, Z.M., Shen, H.S., 2008. Postbuckling of 3D Braided Composite Cylindrical Shells Under Combined External Pressure and Axial Compression in Thermal Environments. Int $\mathbf{J}$ Mech Sci, 50, 719-731. doi:10.1016/j. ijmecsci.2007.12.001.

11. Liu, W., Soden, P.D., Kaddour, A.S., 2005. Design of End Plugs and Specimen Reinforcement for Testing $\pm 55^{\circ}$ Glass/epoxy Composite Tubes Under Biaxial Compression. Comput Struct, 83, 976-988. doi:10.1016/ j.compstruc.2004.11.004.

12. Xia, M., Kemmochi, K., Takayanagi, H., 2001. Analysis of Filament-wound Fiber-reinforced Sandwich Pipe Under Combined Internal Pressure and Thermomechanical Loading. Compos Struct, 51, 273-283. doi:10.1016/ S0263-8223(00)00137-9.

13. Martens, M., Ellyin, F., 2000. Biaxial Monotonic Behavior of a Multidirectional Glass Fiber Epoxy Pipe. Compos Part A Appl Sci Manuf, 31, 1001-1014. doi:10.1016/ S1359-835X(00)00041-5.

14. Gargiulo, C., Marchetti, M., Rizzo, A., 1996. Prediction of Failure Envelopes of Composite Tubes Subjected to Biaxial Loadings. Acta Astronaut, 39, 355-368. doi:10.1016/S00945765(96)00081-1.

15. Tomblin, J., Sherraden, J., Seneviratne, W., Raju, K.S., 2002. A-Basis and B-Basis Design Allowables for Epoxy Based Prepreg. Toray T700GC-12K-31E/\#2510 Unidirectional Tape. AGATE-WP3.3-033051-132.

16. Solvay. Technical Data Sheet Cycom® 381 Prepreg 2021. https://catalogservice.solvay.
com/downloadDocument?fileId=MDkwMTY2 OWM4MDU1YmZmNg==\&fileName $=\mathrm{CYCO}$ M 381_CM_EN.pdf\&base=FAST.

17. Puck, A., Schürmann, H., 2004. Failure Analysis of FRP Laminates by Means of Physically Based Phenomenological Models. Fail Criteria Fibre-Reinforced-Polymer Compos, 264-97. doi:10.1016/B978008044475-8/50011-1. 
